\title{
ADVANCED PROBLEM-BASED LEARNING. THE EXPERIENCE OF THE EUROPEAN UNIVERSITIES PARTICIPANTS TO THE TEMPUS MEDIS PROJECT
}

\begin{abstract}
О.М. Галчонков, Н.В. Лозієнко. Проблемно-орієнтоване навчання підвищеного типу. Досвід європейських університетів, які беруть участь в проекті TEMPUS MEDIS. На базі досвіду європейських університетів, які беруть участь у проекті TEMPUS MEDIS, висвітлено зміст проблемно-орієнтованого навчання та проблемноорієнтованого навчання підвищеного типу. Описано впровадження проблемно-орієнтованого навчання підвищеного типу в навчальний процес сучасних спеціалістів промислових систем управління. Авторами представлено сучасний європейський досвід у сфері навчання сучасних спеціалістів промислових систем управління, отриманий в рамках виконання проекту MEDIS за програмою TEMPUS, в рамках якого п'ять європейських університетів діляться досвідом із шістьма університетами з Казахстану, Росії й України.

Ключові слова: проблемно-орієнтоване навчання, промислові системи управління, модернізація навчальних курсів.
\end{abstract}

O.M. Galchonkov, N.V. Loziienko. Advanced problem-based learning. The experience of the European universities participants to the TEMPUS MEDIS project. Based on the experience of the European universities participants to the TEMPUS MEDIS project contents of the problem-based learning and advanced problem-based learning are highlighted. Integration of the advanced problem-based learning in the modern industrial system control specialists training is described. Authors declared modern European experience in the field of modern industrial system control specialists training gained in the frames of TEMPUS MEDIS project within which five European universities shared their experience with six universities in Kazakhstan, Russia and Ukraine.

Keywords: problem-based learning, industrial system control, training courses modernization.

Introduction. The expanding automation, constant growth and upgrade of nomenclature and complexity of the used software and hardware are the specific features of the modern manufacturing. They lead to an inconsistency between the limited university education duration and the constant growth of the proficiency level the students should have in order to solve particular problems of the modern manufacturing automation. This strong inconsistency in the control systems area specifically sets the differences of its problem-based learning (PBL) from the traditional PBL in other areas.

Literature review. The intensification of industrial automation as well as other factors has induced the appearance of new training methods. PBL became one of these methods; it started its development in the 1950...60's and has become a widely used approach in higher education since 1990's. [1]

The traditional training methodology is characterized by the following:

1. Lectures have the key part in training.

DOI 10.15276/opu.2.46.2015.33

(C) 2015 The Authors. This is an open access article under the CC BY license (http://creativecommons.org/licenses/by/4.0/). 
2. The course is divided into separate modules studied one after the other with no specific emphasis on their joint usage.

3. The laboratory researches, practical trainings and course works are dedicated to certain topics and are of minor importance.

4. The professor has a central role.

5 . The number of students is large (25...30 people).

6. Examinations are the main assessment method.

The usage of this methodology leads to that the students are in possession of vast academic knowledge, the major part of which will never be used at a particular manufacturing where they will be working. At the beginning of their work they need a lot of time to adapt to the software, devices and the development technologies used in the modern manufacturing. At the same time the enterprises are aimed at the production, so they are in need of qualified specialists in the first place, and are not exactly oriented towards the extra training of the university graduates.

The PBL methodology was developed to overcome this inconsistency. Despite the fact that different universities have their own specific organization and PBL courseware, some basic principles may be singled out. The key principle is that the training of the students involves solving of different cases, with the students themselves forming the questions necessary for the case solving and finding the answers to them on the basis of relevant information and joint discussion [2]. There are no lectures at all or very few of them and they are dedicated only to the topics connected directly to particular cases. The classes are given for small groups. The subject syllabus is not divided into topics, but integrated into problem-based cases. The professor's key function as a knowledge source is replaced with the role of a tutor which only controls the process of case solving and, when necessary, channels it appropriately. The knowledge assessment is not single-pointed, but integrated into the process of the case solving.

The usage of such methodology leads to that the students gain practical experience in solving of the problems specific for their specialty, starting from their definition and finishing with their implementation and maintenance. The student don't gain the academic knowledge of their major in full, but they acquire a full set of problem-solving skills, starting from the definition and finishing with the practical implementation which allows them to successfully solve by analogy the problems, for the solving of which they didn't have the initial basic academic background. In other words, the graduates become the specialists fully ready to work in a narrow practical area and are capable of taking the solution of a new similar problem to the practical level quickly and confidently. The cooperation of the universities with each other and with the industry provides the covering of all the needs in all the possible specializations due to their distribution among different universities [3].

However, the technological progress never stalls, as new software, hardware, applications, etc. are being developed. It leads to the constantly growing difference between the education level of the school graduates which enroll at a university and the required proficiency level of the university graduates. That is why a necessity arose for the transformation of classical PBL into advanced problembased learning (APBL). The main specific feature of this methodology is that several interconnected subjects are studied together and the solved cases are not limited by the contents of one course, but require a complex usage of all the courses and may be solved with the help of different sets of hardware and software [4...7]. The students learn all the possible solutions of the cases which allows them to freely operate all the possible range of technologies and choose the best variant in each practical situation in the future.

Aim of the Research is to cover the key approaches and principles of the advanced problembased learning of the modern industrial control systems development used by leading European universities.

Main Body. The APBL requires more complex courseware as compared to the classical PBL as it is necessary to plan simultaneous learning of several subjects (course units) which are studied sideby-side and develop the cases, the solving of which suggests complex usage of the decisions offered by different courses. 
The APBL-cases have two versions, one for the students, and one for the teachers. The teachers' version has a full description of the situation and the essential information which the students have to gather from all the course units as well as the description of actions undertaken in certain situations for the solving of the specific problem or prevailing it in each possible variants. The usage techniques for the required hardware and software as well as the explanation of some notions, necessary formulae and indexes are also given here. In that way the teacher knows what the students have to discuss, in what order the decision-making should be done, what should be used as the basic hardware and software modules and what are the possible solutions of the case. An important part is the controlled object (CO) introduced at the very beginning of the case (only in the teachers' version) for which the students should unsupervisedly form the volume of the analyzed information, the ways and accuracy of its obtaining, the adjustment devices and the ways of operating them. Before doing some practical actions the students should discuss and introduce the solutions of the problem in whole which were chosen within the group.

The students' version of a case suggests the studying of the required hardware and software one after the other. Every device required for the problem solution in general should be previously studied apart from the others. The aim of these small substeps is the studying of both the ware and the methods of its isolated testing which gives an opportunity to find out the reason for the failure to work of the big system consisting of a substantial quantity of different units. The next step is the gradual increment of the equipment and ware up till the development of a whole system. With that, every new increment should be tested for the correct work of the procured complex of devices. An essential moment in the case solution is to teach the students how to work with technical documents. On the basis of general understanding of the hardware and software structure and their documentation, the students are to quickly learn to find the relevant information in technical specifications which consist of thousands of pages. The second important moment should be the elaboration of the students' skills for using the programmers examples and the ways of operating which are provided both by the hardware and software producers and the development environments producers.

The third important moment is to teach the students how to produce documents for the computed solution of a case, how to present both the intermediary result and the final solution as well as how to produce the documentation which justifies the correctness and effectiveness of the planned and performed actions. The fourth moment which shows the strong distinction of APBL from PBL is the different role of a teacher. In APBL he is not a tutor but more of a stalker, i.e. a guide which helps to find at least one solution for the problem in hand. The modern development environments of hardware and software are quite complex products with wide functionality which are constantly upgraded and added. The whole studying of these wares all the more without any relation to a certain problem requires a lot of time and effort from the students. In APBL the students, first supervised by a professor, study one of the ways of getting from the initial task in general to an operating device. Later, the circle of the equipment in use and the amount of the necessary efforts from the students increase gradually for the unsupervised studying of the sub-solutions of a problem. Thus, the students acquire not just the basic approach to the solving of the certain type of problems, but also learn about the development environments together with the profound knowledge of these environments.

In the TEMPUS MEDIS project the implementation of APBL looks this way. The aim is to train the students in such a way which corresponds to the level of specialists fully proficient in the developing of modern industrial control systems. In order to do that the course units are put together and will be studied both one apart from another and interconnected:

The usage of the industrial computers together with the signal input and output facilities (to control a particular object which could be, for example, a water container with a water booster pump, an outflow valve, water level sensor, etc.)

The usage of the modern microcontrollers to build the control systems (a certain controller and a software development environment for it are taken for operation of the same object, for instance, the evaluation module STM32F429IDISCOVERY and development environment IAR or KEIL). 
The usage of standard field buses for the construction of distributed industrial control systems (RS232, RS485, I2C, CAN, MODBUS, etc.)

The usage of a wireless communication channel for the development of the distributed industrial control systems (Bluetooth and Wi-Fi for the connection between tablets, between tablets and desktop computers, between tablets and microcontrollers, etc.)

The modeling of the industrial control systems (in relation to those used in the previous subjects of hardware, software and controlled objects).

For each subject the classes are held in the form of lectures, seminars, laboratory researches and mini-projects:

Lectures: the teacher sets out the basic theory related to the planned mini-projects, their importance for practical application, the full range of the hardware and software which could be used in the projects, and the design technology and environment. Apart from the basic method of a miniproject implementation through the given course, the alternative variants are definitely listed which are studied as the basic ones at the other subject units of other courses.

Seminars: are carried out in the form of discussion within the students' team (of 4 students) at the core of which is the current state of mini-projects, the presentation of the accomplished steps with the analysis of the usage peculiarities of the chosen hardware and software, the planning of the next step for the mini-projects implementations.

Laboratory researches: the basic for this course hardware and software are studied which are necessary for the mini-projects implementation. The students work in pairs and acquire basic set of skills related to the topics presented in the lectures. The tasks in the laboratory researches resolve particular and clear-set problems; they have guidelines, are fully documented and their complexity gradually increases. For instance, the following tasks could be used: create a project in the design environment IAR for a microcontroller, input a discrete signal from a sensor, output a discrete signal to an actuator, input an analog signal from a sensor, output a signal from the pulse-width modulation for the DC motor control, display the control process on the screen of a microprocessor, etc. The teacher helps the students in the usage of the design environments for the progress from the problem definition to the working device. The teacher should monitor the students' practical training by answering their questions and guiding them using hints enough to make them find some of the solutions themselves. The typical mistakes, problems, and interesting approaches found during the laboratory research should be discussed with the whole group.

Mini-projects: the students integrally use their knowledge and skills which they have acquired during the lectures, laboratory researchers and seminars for the full-scale development of the physical process controller. At every next stage the hardware and software are added which are being studied at the parallel courses. For instance, at the first step the object control is done with the help of the microcontroller fireware with the display of the controllable parameters on its screen. At the second stage, an industrial computer is connected to the used equipment through the MODBUS and on its monitor the control processes are displayed. At the third stage, the second microcontroller is connected to the first controller through the CAN bus which receives data from the additional sensors. At the fourth stage, a wireless channel is added between one of the microcontrollers and the tablet, and the control of the physical process simultaneously from the industrial computer and tablet is implemented. At every stage, the controller configuration which will be implemented on this stage is preliminary modulated together with the object of the control for the test of the work correctness of the used regulators in all the possible function modes of the controlled object.

It should be pointed out that lectures and laboratory researches are clearly related to their subjects. Mini-projects and seminars have the form of interdisciplinary classes. After the mini-project the students are to be capable of integrating the instruments and procedures practiced during the course units in order to develop non-complex medium-sized applications for control of the physical processes. They also should be able to document the developed hardware and software and give a presentation on the process of the mini-project implementation and its results. 
Results. As well as in classical PBL, one of the essential conditions for the APBL is the active cooperation among the students aimed at quicker and more diverse gain of the required knowledge and skills, and also the group decision-making, the ability to work in a team. An important advantage of APBL is the training of the development skills on the basis of a whole unit of courses. Moreover, the projects are implemented in the format which is as close as possible to the requirements of an industry, i.e. the following takes place:

- The general definition of the problem;

- The team work on the project;

- The choice and justification of the most effective problem solution;

- The choice of the most effective hardware and software for the problem solution;

- The project review;

- The practical realization of the project;

- Set-up activities;

- Acceptance tests for all the function modes;

- Full documenting of the implemented project;

- A presentation of the project.

An important advantage of ABPL as compared to the traditional learning is the creation of the positive motivation to study through the feeling of an achievement of a practically meaningful result which is in-demand in real life. The students become more confident, they acquire a portfolio of the problems they are capable of solving on a high level. This, in its turn, leads to the sense of accomplishment from the learning process, higher self-esteem and acknowledgement from others.

Conclusions. The TEMPUS MEDIS project is aimed at the integration of APBL into the modern industrial control systems specialists training. However, the APBL itself allows to increase the effectiveness of the education in any activity areas due to the gradually increasing requirements to the higher education institutions graduates. These may be both the practical side of certain industrial types of activity and the scientific researches in some areas, creative projects, informational (introductory and tentative) projects, etc. The main principle implemented here is that the knowledge and skills are gained not only for some future use, but for a specific type of activity. And the level of these knowledge and skills should provide the carrying out of this activity on the highest technological level not just now but in the future as well, as the university graduates will know not only how to make something on a high level, but how to keep to this level at all times.

\section{Література}

1. Rhem, J. Problem-Based Learning: An Introduction [Електронний ресурс] / J. Rhem // The National Teaching \& Learning Forum. — 1998. — Vol. 8, No. 1. — Режим доступу: http://utminers.utep.edu/ robertson/pdf/introduction_pbl_article.pdf (Дата звернення: 31.03.2015).

2. Искренко, Э.В. Проблемно-ориентированное обучение: особенности методики преподавания в Великобритании (на примере St.George University of London, Great Britain) / Э.В. Искренко, Т.А. Полтон // Научные ведомости БелГУ. Серия: История. Политология. Экономика. Информатика. - 2008. - Т. 10, Вып. 8. - С. $214-218$.

3. Innovative methodology to improve the quality of electronic engineering formation through teaching industrial computer engineering / H. Hassan, J.-M. Martinez, C. Dominguez et al. // IEEE Transactions on Education. - 2004. - Vol. 47, Issue 4. - PP. 446 - 452.

4. Ten Years of Cybertech: The Educational Benefits of Bullfighting Robotics / M. Hernando, R. Galan, I. Navarro, D. Rodriguez-Losada // IEEE Transactions on Education. - 2011. — Vol. 54, Issue 4. PP. $569-575$.

5. Savery, J.R. Problem-based learning: An instructional model and its constructivist framework / J.R. Savery, T.M. Duffy // В кн.: Constructivist Learning Environments: Case Studies in Instructional Design / ed. by B. Wilson. — Englewood Cliffs, NJ: Educational Technology Pub., 1996. — PP. 135 - 150.

6. Remote Laboratory Architecture for the Validation of Industrial Control Applications / H. Hassan, C. Dominguez, J.-M. Martinez et al. // IEEE Transactions on Industrial Electronics. - 2007. Vol. 54, Issue 6. - PP. $3094-3102$. 
7. Integrated Multicourse Project-based Learning in Electronic Engineering / H. Hassan, C. Dominguez, J.-M. Martinez et al. // International Journal of Engineering Education. - 2008. - Vol. 24, No. 3. PP. $581-591$.

\section{References}

1. Rhem, J. (1998). Problem-based learning: An introduction. The National Teaching \& Learning Forum, 8(1). Retrieved on 15 March 2015, from http://utminers.utep.edu/robertson/pdf/introduction_pbl_article.pdf

2. Iskrenko, E.V. and Poulton, T.A. (2008). The specificity of problem based learning: the technique in operation at St.George University of London, Great Britain. Belgorod State University Scientific bulletin: History, Political science, Economy, Information technology, 10(8), 214-218.

3. Hassan, H., Martinez, J.-M., Dominguez, C., Perles, A. and Albaladejo, J. (2004). Innovative methodology to improve the quality of electronic engineering formation through teaching industrial computer engineering. IEEE Transactions on Education, 47(4), 446-452.

4. Hernando, M., Galan, R., Navarro, I. and Rodriguez-Losada, D. (2011). Ten years of Cybertech: The educational benefits of bullfighting robotics. IEEE Transactions on Education, 54(4), 569-575.

5. Savery, J.R. and Duffy, T.M. (1996). Problem-based learning: An instructional model and its constructivist framework. In B. Wilson (Ed.), Constructivist Learning Environments: Case Studies in Instructional Design (pp. 135-150). Englewood Cliffs, NJ: Educational Technology Pub.

6. Hassan, H., Dominguez, C., Martinez, J.-M., Perles, A. and Albaladejo, J. (2007). Remote laboratory architecture for the validation of industrial control applications. IEEE Transactions on Industrial Electronics, 54(6), 3094-3102.

7. Hassan, H., Dominguez, C., Martinez, J.-M., Perles, A.; Albaladejo, J. and Capella, J-V. (2008). Integrated multicourse project-based learning in electronic engineering. International Journal of Engineering Education, 24(3), 581-591. 